\title{
A Meiotic Study of the Wild and Semi-domesticated Brazilian Species of Genus Capsicum L. (Solanaceae)
}

\author{
Marisa Toniolo Pozzobon ${ }^{1, *}$ and Maria Teresa Schifino-Wittmann ${ }^{2}$ \\ ${ }^{1}$ Embrapa Recursos Genéticos e Biotecnologia, CENARGEN, Estação Biológica-PqEB-Final W5 Norte. CP \\ 02372, Brasília, DF, 70770-900, Brazil \\ ${ }^{2}$ Departamento de Plantas Forrageiras e Agrometeorologia, Faculdade de Agronomia, Universidade Federal do \\ Rio Grande do Sul, Caixa Postal 15100, 91501-970, Porto Alegre, RS, Brazil
}

Received June 11, 2006; accepted June 21, 2006

\begin{abstract}
Summary Meiotic behavior was analysed in 30 accessions of 12 wild (Capsicum flexuosum, C. parvifolium, C. buforum, C. campylopodium, C. cornutum, C. pereirae, C. friburgense, C. schottianum, C. villosum var. villosum, and 3 new species) and 2 semi-domesticated (C. baccatum L. var praetermissum and C. chinense) Brazilian Capsicum species. This is the first report on meiosis for most of these taxa. Except for $C$. baccatum L. var praetermissum, $C$. chinense, $C$. flexuosum and $C$. parvifolium, with $2 n=24$ chromosomes, all other taxa had $2 n=26$ chromosomes, a number previously considered as not common in the genus. Meiotic pairing was generally regular (12 or 13 bivalents) for most of the species analyzed. However, different irregularities such as univalents, multivalents, bridges, chromosome stickiness, unoriented chromosomes, monads, dyads and polyads, among others, were found at both meiosis I and meiosis II, leading to unbalanced final meiotic products but generally not a high pollen sterility. It was not possible to establish with certainty if these irregularities were due to genetic (meiotic mutations) or environmental (such as pests and diseases) causes.
\end{abstract}

Key words Brazilian peppers, meiotic behavior.

Chile peppers (genus Capsicum), a popular and profitable culture grown in the tropics and temperate regions, are among the main cultivated vegetables and spices. Some species and varieties are also used for ornamental and medicinal purposes. However, there are serious phytosanitary and quality problems that may be overcome by selection and breeding. In Capsicum, resistance to pests and diseases is normally an attribute of a given accession and not of the whole species (González and Bosland 1991), therefore the variability found in the wild species represent valuable genetic resources to be explored.

The exact generic and infra-specific delimitations are still controversial but 20 to 30 wild and semi-domesticated species and 5 cultivated ones (Capsicum annuиm L. var. annuиm, C. baccatum L. var. pendulum (Willd.) Eshbaugh, C. chinense Jacq., C. frutescens L. and C. pubescens Ruiz and Pavon) are presently recognized, all of them native to the New World (McLeod et al. 1979a, 1979b; McLeod et al. 1983a, 1983b).

Different approaches such as morphological, immunological, flavonoid and isozymes patterns and molecular markers analyses, aimed at establishing genetic and evolutionary relations among Capsicum species have been disclosing polymorphisms.

As for cytogenetics, karyotype aspects have been studied in wild and domesticated species (Pickersgill 1971, 1977, 1991, Limaye and Patil 1989, Moscone 1990, 1993, 1999, Bertão 1993, Moscone et al. 1993, 1995, 1996, Tong and Bosland 1997, 2003, Ferreira 1998, Park et al. 2000). In all these studies, $x=12$ (mostly as $2 n=24$ ) have been cited as the predominant basic number in

*Corresponding author, e-mail: marisa@cenargen.embrapa.br 
the genus, while $x=13(2 n=26)$ was found in only in 5 taxa (C. ciliatum (H., B. \& K.) Kuntze, $C$. lanceolatum (Green.) Morton \& Stand., C. mirabile Martius, C. campylopodium Sendtner and 1 unidentified Capsicum sp. However, Pozzobon et al. (2006) recently found $2 n=26$ for 9 more species from Brazil and suggested that $x=12$ and $x=13$ represent different evolutionary trends in the genus. Meiotic behavior evaluation has been performed in the $x=12$ wild and domesticated species as well as in some hybrids, aiming at verifying genomic diversification during evolution as well as possible inter-specific phylogenetic relations (Otha 1961, Lippert et al. 1966, Shopova 1966a, 1966b, Carluccio and Saccardo 1977, Pickersgill 1971, 1977, 1991, Saccardo and Ramulu 1977, Egawa and Tanaka 1984, Mirkova and Molchova 1985, Kumar et al. 1987, Raghuvanshi and Saxena 1991, Moscone 1992, Bapa Rao et al. 1992, Lanteri and Pickersgill 1993, Tong and Bosland 1999, Panda et al. 2004). However there are few reports (Tong and Bosland 1997, 2003) on meiotic behavior of the $x=13$ taxa.

Southeastern Brazil is considered to have the largest number of wild Capsicum species (at least 10 different taxa), being the biggest diversity center of wild species. (Pickersgill 1984, Bianchetti 1996). Most of them are distributed along the Atlantic Rain Forest and threatened by genetic erosion due to anthropic pressure. These potential genetic resources have not been properly used for Capsicum breeding or evolutionary studies mainly due to the bottleneck of lack of basic information as chromosome numbers and meiotic behavior.

Therefore, the objective of the present work was to analyze the meiotic behavior of the EMBRAPA-Hortaliças (Brazilian Agricultural Research Corporation-Horticulture) Distrito Federal, Brazil, collection of wild and semi-domesticated Brazilian Capsicum species and accessions.

\section{Material and methods}

A total of 30 accessions of 14 species were analyzed: the semi-domesticated C. baccatum L. var. praetermissum (Heiser and Smith) Hunz., and C. chinense Jacq., and the wild C. flexuosum Sendtner, C. parvifolium Sendtner, C. buforum Hunz., C. campylopodium Sendtner, C. cornutum (Hern.) A. T. Hunziker, C. schottianum Sendtner, C. villosum Sendtner var. villosum, 2 new species C. pereirae Hunz. and C. friburgense Hunz. (Barboza and Bianchetti 2005) and 3 other putative new species, here referred as Capsicum sp 1, Capsicum sp 2 and Capsicum sp 6 (Table 1). Except for C. baccatum L. var. praetermissum, C. chinense, C. flexuosum and C. parvifolium $(2 n=24)$ all other taxa have $2 n=26$ (Pozzobon et al. 2006).

The material analysed originated from plants directly collected from natural populations, as well as from plants obtained from seeds collected from natural populations, both grown in greenhouse and experimental field at EMBRAPA-Hortaliças. Some accessions were also maintained in pots in a greenhouse at Departamento de Plantas Forrageiras and Agrometeorologia, Universidade Federal do Rio Grande do Sul (Department of Forage Plants and Agrometeorology, Federal University of Rio Grande do Sul), Porto Alegre, RS, Brazil. For some of the accessions, more than 1 individual was grown (identified by letters in Table 2).

Taxonomic vouchers for each accession are kept at EMBRAPA-CENARGEN (National Genetic Resources and Biotechnology Center), Brasília, DF, Brazil.

For meiotic studies, young flowers were fixed in a mixture of $3: 1$ ethanol-acetic acid for $24 \mathrm{~h}$, and stored in $70 \%$ ethanol below $0^{\circ} \mathrm{C}$ until required. Slides were prepared by squashing the anthers in $2 \%$ propionic carmine. To analyze chromosome pairing, the highest available number of wellspread cells at diakinesis and metaphase were examined. Besides, to follow all the meiotic process, all available and well-spread cells in any other meiotic phase were examined. Meiotic indexes were estimated following Love (1949). Those tetrads with 4 equal-sized cells were considered as normal, and any deviation as abnormal. Pollen fertility was estimated by analyzing at least 1000 mature pollen grains per plant. Well stained grains were considered as fertile and empty ones as sterile. 
Table 1. Capsicum species, accession number, collector identification and origin of the accessions examined

\begin{tabular}{|c|c|c|c|}
\hline $\begin{array}{l}\text { Species, } \mathrm{CNPH}^{1} \\
\text { accession number, } \\
\text { collector's }{ }^{2} \text { number }\end{array}$ & Place of collection ${ }^{3}$ & $\begin{array}{l}\text { Species, } \mathrm{CNPH}^{1} \\
\text { accession number, } \\
\text { collector's }{ }^{2} \text { number }\end{array}$ & Place of collection ${ }^{3}$ \\
\hline Semi-domesticated & & C. villosum var. villosum & \\
\hline C. baccatum L. var. & praetermissum & 3313, LBB 1538 & Estação Biológica da Boracéia, SP \\
\hline 3325, LBB 1553 & Caldas, MG & 3314, LBB 1539 & Estação Biológica da Boracéia, SP \\
\hline 3326, LBB 1555 & Maria da Fé, Pedrão, MG & 3317, LBB 1543 & Estação Biológica da Boracéia, SP \\
\hline C. chinense & & 3328, LBB 1557 & Parque Nacional do Itatiaia, RJ \\
\hline 3727, LBB 1720 & Vila Apiaú, Roraima, RR & Capsicum sp $1^{4}$ & \\
\hline Wild & & 3301, LBB 1521 & Parque Estadual Carlos Botelho, SP \\
\hline C. flexuosum & & Capsicum sp 2 (Oito dentes) ${ }^{4}$ & \\
\hline 3324, LBB 1552 & Caldas, MG & 3302, LBB 1523 & Parque Estadual Jacupiranga, SP \\
\hline C. parvifolium & & 3372, LBB 1525 & Estação Ecológica Juréia, Itatins, SP \\
\hline 3331, LBB 1560 & Univ. Federal de Viçosa, MG & Capsicum sp 6 (Piquete) $^{4}$ & \\
\hline C. buforum & & 3330, LBB 1559 & Lima Duarte, MG \\
\hline 3367 , LBB 1550 & $1 \mathrm{~km}$ da Estação Eugene Lefévre, SP & 3337, LBB 1568 & Parque Nacional do Caparaó, MG \\
\hline 3368, LBB 1554 & Maria da Fé, EPAMIG, MG & 3370, LBB 1564 & Parque Nacional Serra dos Órgãos, RJ \\
\hline C. campylopodium & & C. pereirae & \\
\hline 3335, LBB 1566 & Santa Maria Madalena, RJ & 3329, LBB 1558 & Parque Estadual do Ibitipoca, MG \\
\hline 3369, LBB 1562 & Parque Nacional da Tijuca, RJ & 3336, LBB 1567 & Castelo, ES \\
\hline C. cornutum & & C. friburgense & \\
\hline 3316, LBB 1542 & Estação Biológica da Boracéia, SP & 3334, LBB 1565 & Nova Friburgo, RJ \\
\hline 3320, LBB 1546 & Paraty-Cunha, SP & & \\
\hline 3365, LBB 1527 & Parque Estadual Serra do Mar, SP & & \\
\hline \multicolumn{4}{|l|}{ C. schottianum } \\
\hline 3310, LBB 1535 & Estação Biológica da Boracéia, SP & & \\
\hline 3311, LBB 1536 & Estação Biológica da Boracéia, SP & & \\
\hline 3315, LBB 1540 & Estação Biológica da Boracéia, SP & & \\
\hline 3318, LBB 1544 & Natividade da Serra-Bairro Alto, SP & & \\
\hline 3319, LBB 1545 & São Luiz de Paraitinga SP & & \\
\hline
\end{tabular}

${ }^{1}$ CNPH-Embrapa Hortaliças.

${ }^{2}$ LBB-Luciano de Bem Bianchetti.

${ }^{3}$ ES-Espírito Santo; MG-Minas Gerais; SP-São Paulo; RJ-Rio de Janeiro; RR-Roraima.

${ }^{4}$ Putative new species, numbered and nicknamed following Bianchetti et al. (1999).

Results were recorded by photomicrographs and digital image capturing.

\section{Results and discussion}

These are the first reports on meiotic behavior of 11 out of the 14 species analyzed. Previous observations on $C$. chinense, $C$. flexuosum and $C$. buforum meiosis have been published and will be discussed further on.

Chromosome pairing at diakinesis and metaphase I, as well as the other phases of meiosis, were predominantly regular for the $2 n=24$ species $C$. baccatum var. praetermissum, $C$. chinense, $C$. flexuosum and C. parvifolium (Table 2). Most of the cells analyzed presented 12 bivalents (II) (Fig. 1A). A few quadrivalentes (IV) were observed in C. chinense, C. flexuosum and C. parvifolium (Fig. 1B), and univalentes (I) em C. flexuosum. In some cells chromosome stickiness hampered the interpretation of pairing configurations (Fig. 1C) and in others chromosome superposition and nonoriented bivalents were observed. Even if in reduced frequencies, meiotic abnormalities were seen (Table 2): irregular disjunction and stickiness at anaphase I (Fig. 1D), laggards, bridges and/or fragments at anaphase and telophase I. Pro-metaphase II and metaphase II were regular $(12+12)$ in 


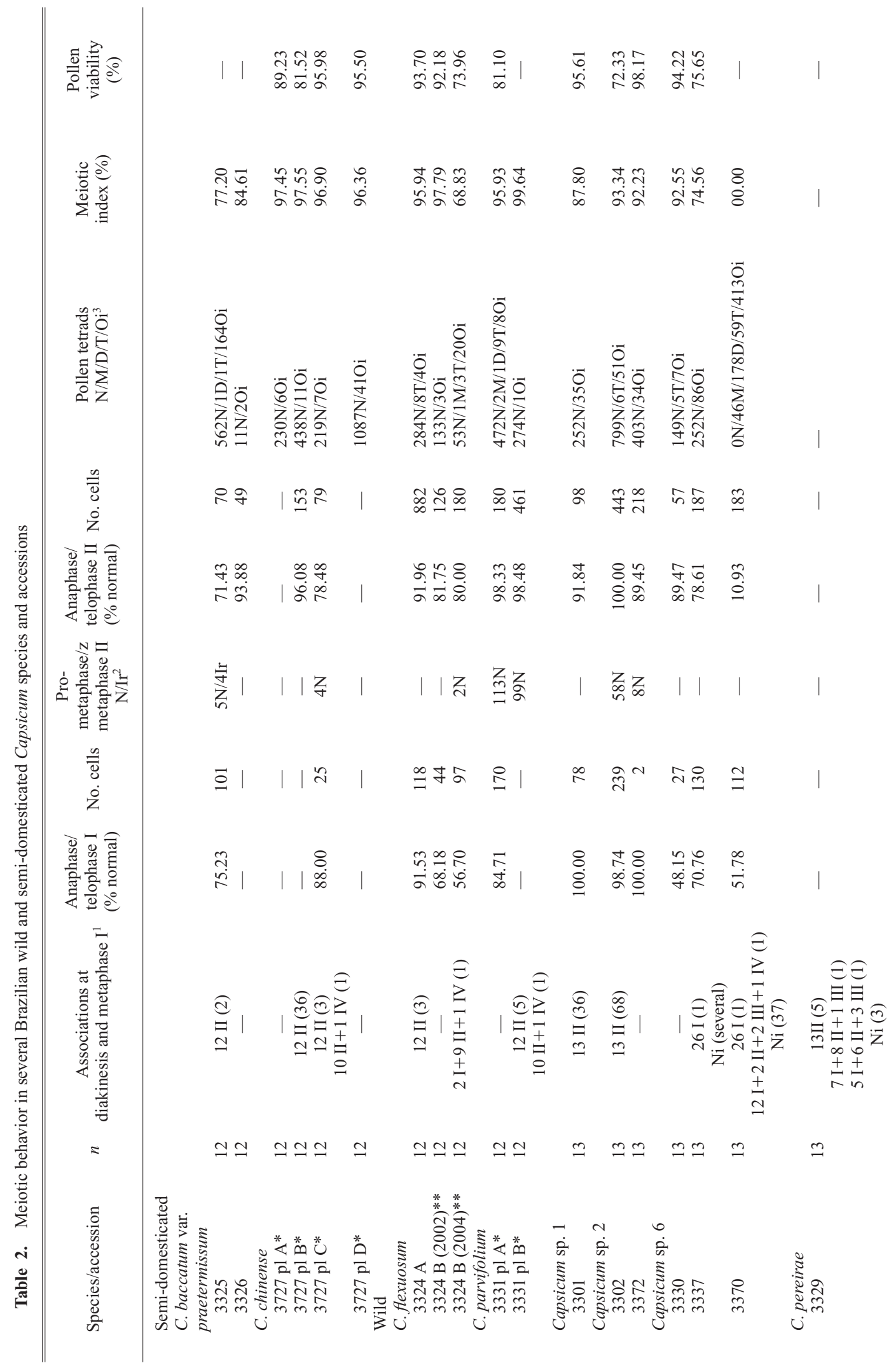




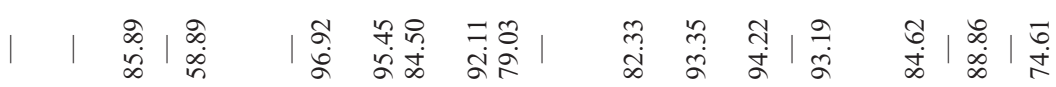

ए

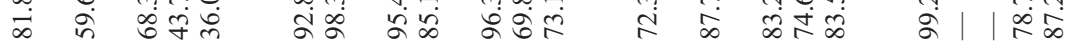

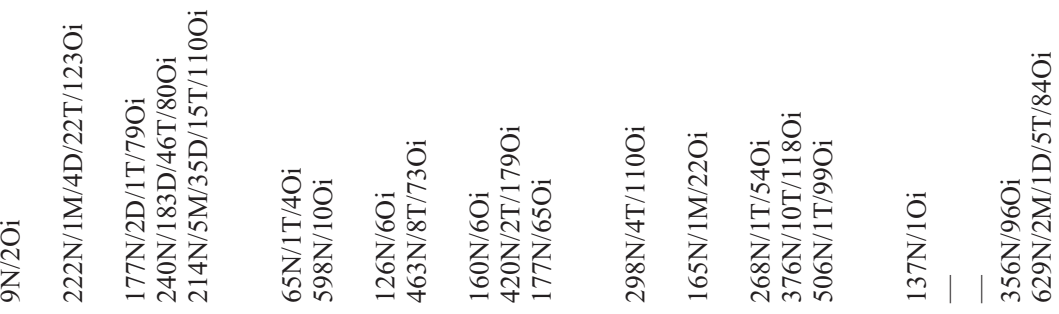

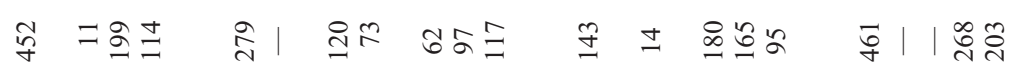

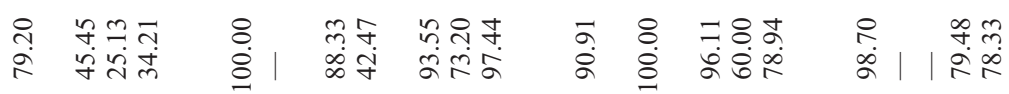

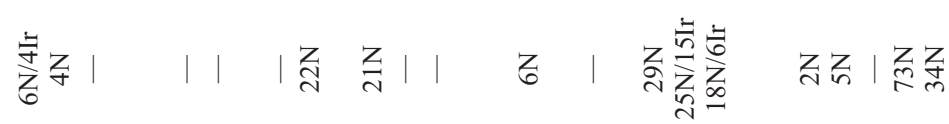

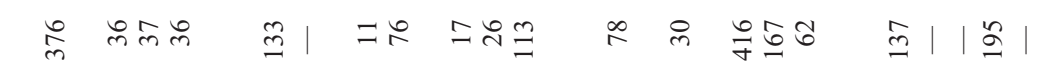

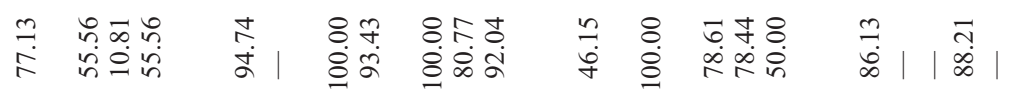

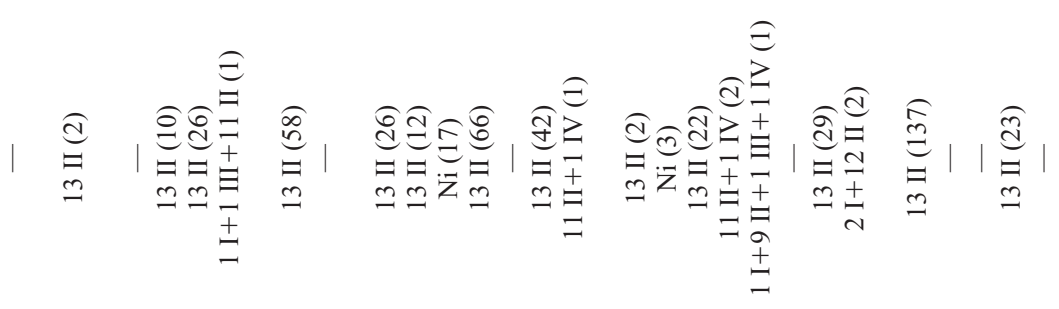

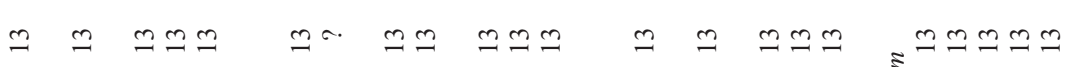

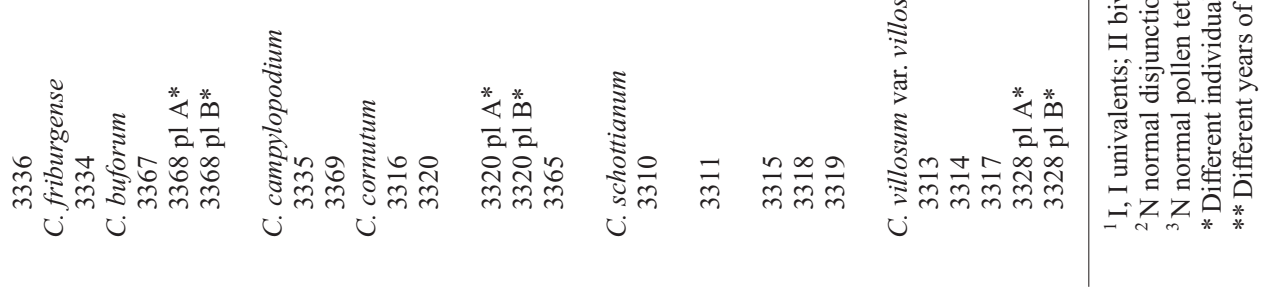



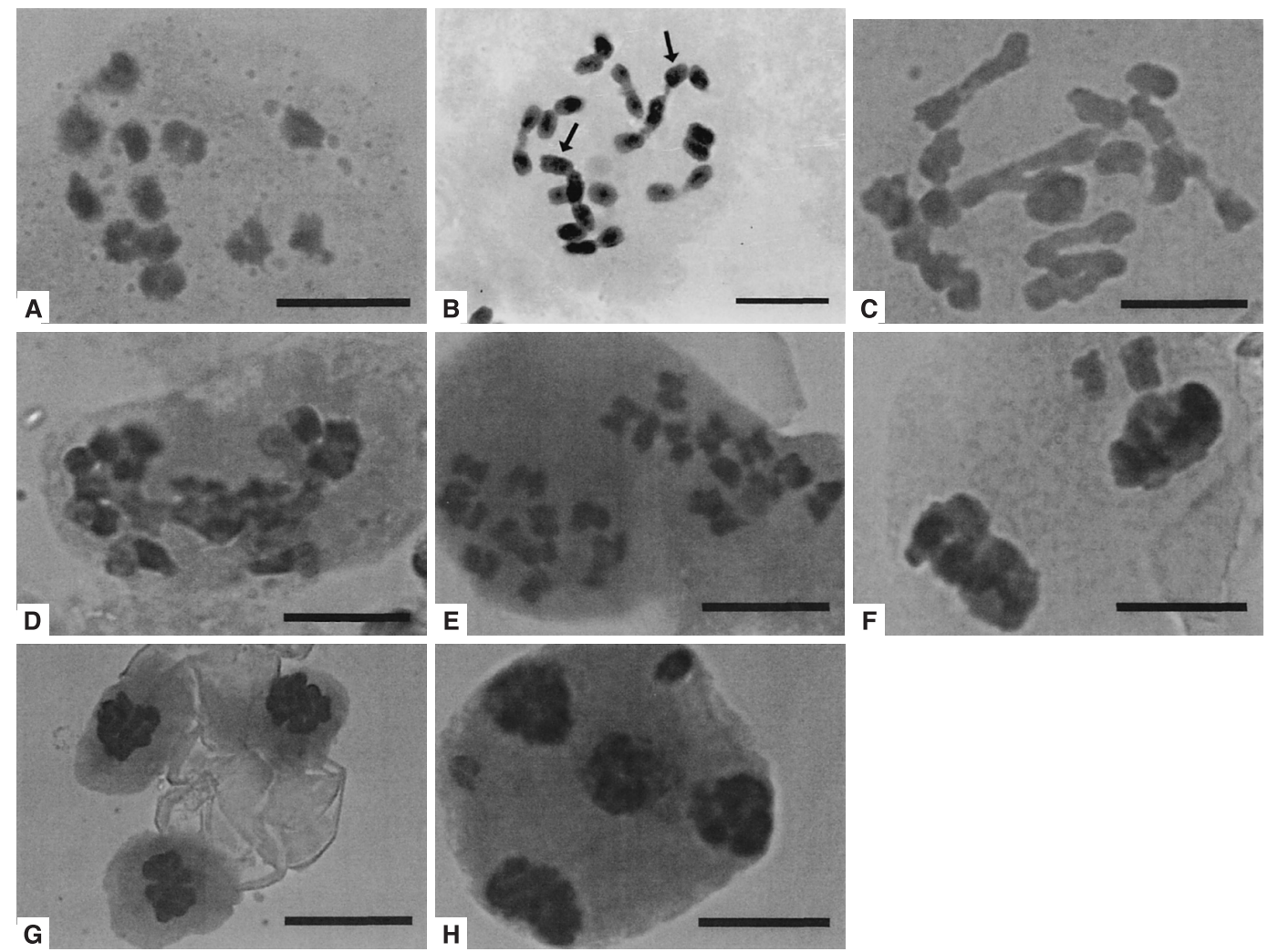

Fig. 1. Meiosis in $2 n=24$ Capsicum species. A) C. chinense, late diakinesis, with 12 bivalents; B) C. parvifolium, late diakinesis with two chain quadrivalents $(\rightarrow)$. C-H) C. flexuosum: C) metaphase I, with chromosome stickiness, D) anaphase I, with bridges, E) pro-metaphase II, with a normal $12+12$ segregation, F) metaphase II, with two chromosomes outside the plate, G) restitution nuclei, H) telophase II with two micronuclei. Scale bar equal to $10 \mu \mathrm{m}$.

most of the cells (Fig. 1E) but chromosomes outside the equatorial plate were observed (Fig. 1F) and in telophase II micronuclei (Fig. 1H) and formation of 3 instead of 4 nuclei were found. Monads were found in C. flexuosum and C. parvifolium (Fig. 2C), dyads in C. baccatum var. praetermissum (Fig. 2B) and C. parvifolium and tryads in C. baccatum var. praetermissum, C. flexuosum and C. parvifolium, probably originated from the restitution nuclei observed between pro-metaphase and anaphase II (Fig. 1G and 2A). Some tetrads with unequal-sized cells, polyads with varying microcyte number and size and micronuclei were seen (Fig. 2F). In C. baccatum var. praetermissum a possible type of chromosome elimination was observed (Fig. 2D and E), in which those chromosomes that appeared as micronuclei in previous meiotic phases were eliminated from the microspore as microcytes. This chromosome elimination have been reported for C. annuum L., C. frutescens L. and C. pubescens Ruiz and Pavon (Shopova 1966b) and is similar to what has been described for Avena sativa L. (Baptista-Giacomelli et al. 2000), but there is no clear explanation for this phenomenon.

Most of the works with the domesticated Capsicum species C. annuum, C. baccatum, C. chinense and C. frutescens reported regular chromosome pairing (12 II) (Kumar et al. 1987, Bapa Rao et al. 1992, Panda et al. 2004) but some meiotic irregularities were are also found (Lippert et al. 1966, Shopova 1966b) and Moscone (1992) observed some abnormalities in 1 accession of the wild $2 n=24$ C. flexuosum. The possible reasons for these irregularities could be hybrid origin and in- 

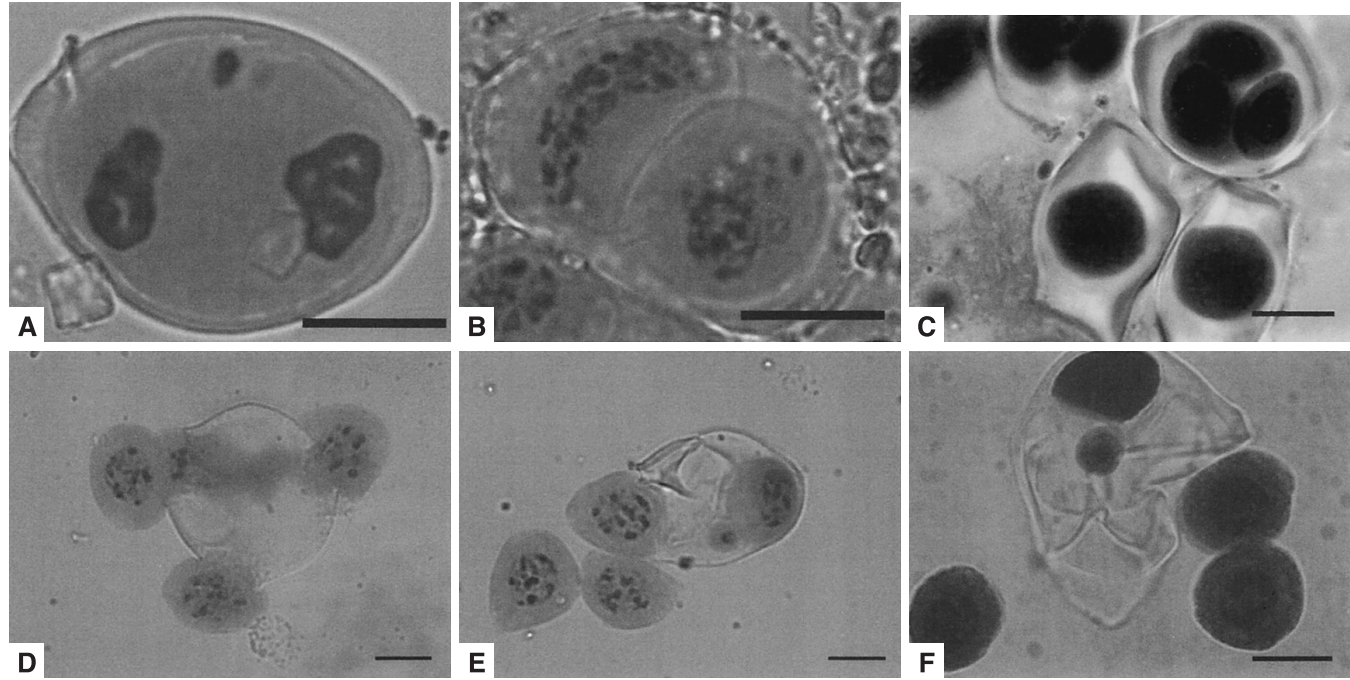

Fig. 2. Meiosis in $2 n=24$ Capsicum species. A and B) C. baccatum var. praetermissum: A) formation of two nuclei and one micronucleus, B) dyad, C) C. parvifolium, monads. D and E) C. baccatum var. praetermissum showing chromosome elimination, F) C. parvifolium, tetrad and microcyte. Scale bar equal to $10 \mu \mathrm{m}$.
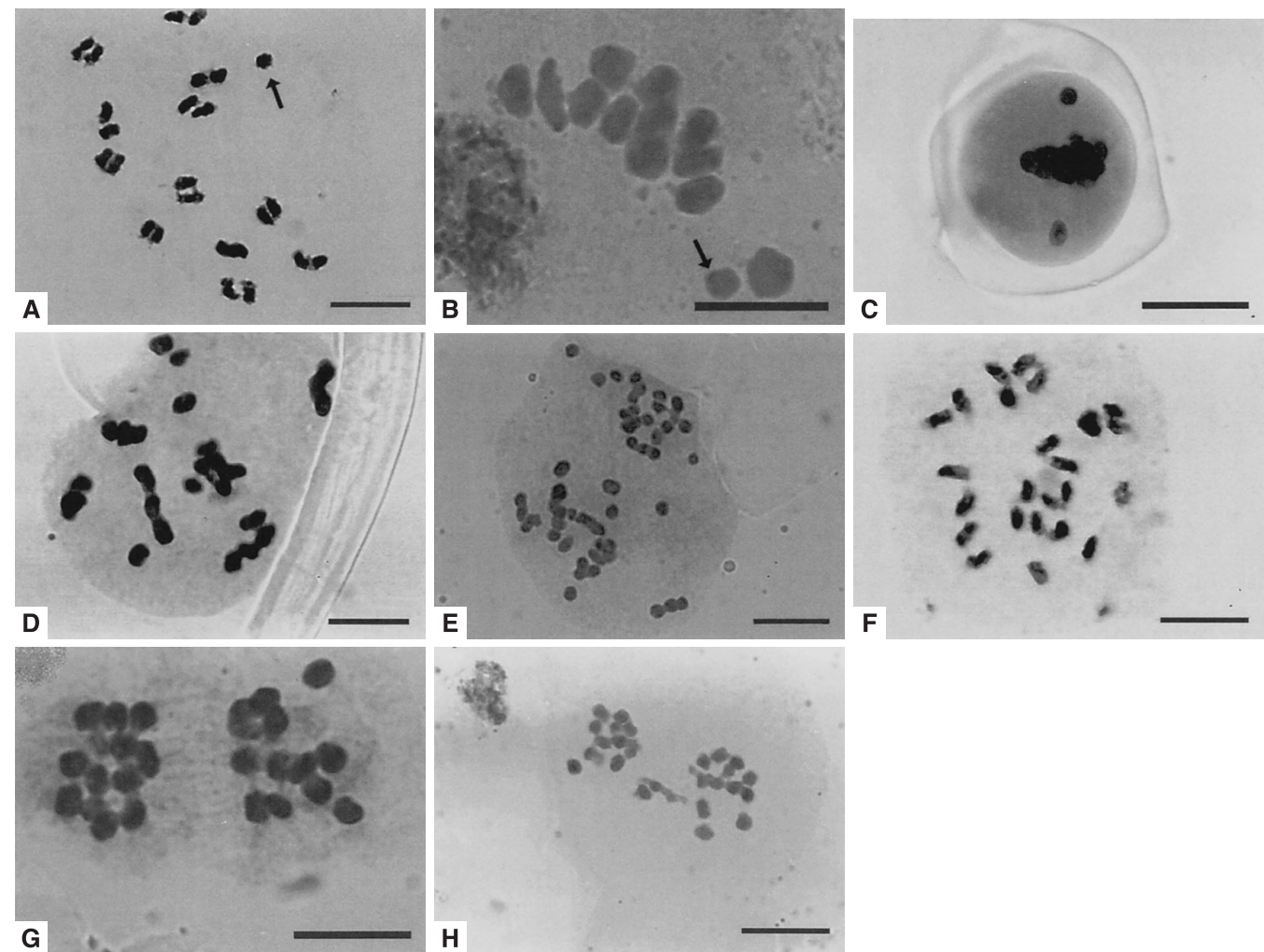

Fig. 3. Meiosis in $2 n=26$ Capsicum species. A) Diakinesis in C. $s p 2$ with 13 bivalents, B and C) C. cornutum: B) metaphase I with 13 bivalents ( $\rightarrow$ small thirteenth pair), C) metaphase I with non-oriented chromosomes, D and E) C. sp 6: D) metaphase I, polar view, with univalents and multiple associations, E) anaphase I with chromatid separation, F and G) C. schottianum: F) bivalents loosely associate at diakinesis, G) anaphase I with $13+13$ chromosome distribution, H) C. pereirae, anaphase I with bridge and fragment. Scale bar equal to $10 \mu \mathrm{m}$. 

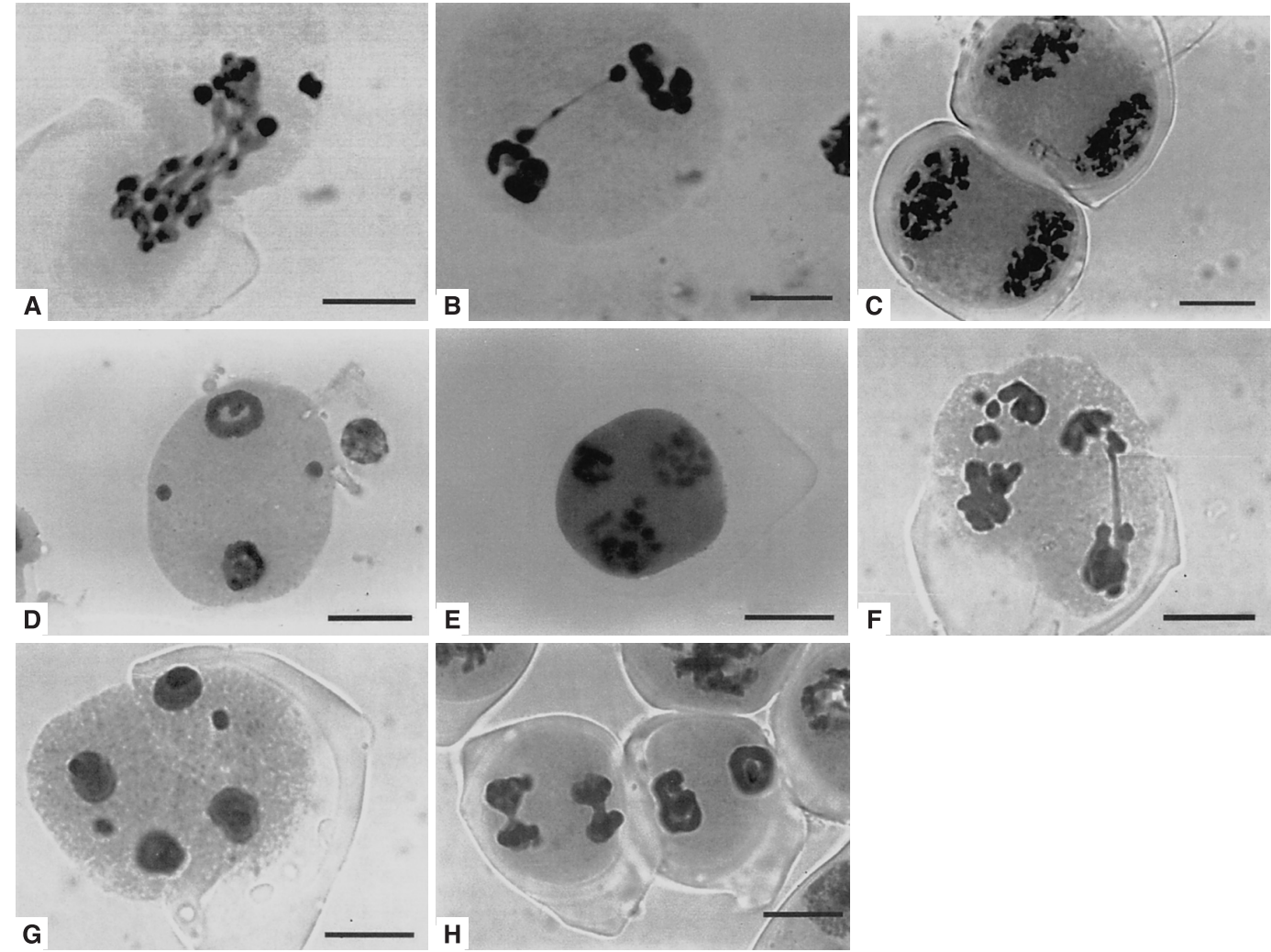

Fig. 4. Meiosis in $2 n=26$ Capsicum species. A) C. $s p$ 6, anaphase I with chromosome stickiness, B) C. villosum var. villosum, telophase I, with bridge, C) C. sp 6, cells with restitution nuclei, D and E) $C$. buforum, cells with formation of two and three nuclei and micronuclei, $\mathrm{F}-\mathrm{H}$ ) C. friburgense: $\mathrm{F}$ ) telophase II with bridge and micronuclei, G) telophase II with micronuclei, H) tellophase II with bridge and formation of two nuclei. Scale bar equal to $10 \mu \mathrm{m}$.

tense self-fertilization which would not necessarily influence fertility (Shopova 1966b, Novák and Betlach 1970).

Meiotic indexes most probably reflect what happens during the second meiotic division. In general, most of the plants with $2 n=24$ analyzed had meiotic indexes over $90 \%$ (Table 2), therefore being considered as meiotically estable and suitable, from the cytological point of view, for plant breeding. C. baccatum var. praetermissum had relatively lower meiotic indexes (77.20-84.61\%) than $C$. chinense and $C$. parvifolium (over 90\%). For C. flexuosum, a broad variation in meiotic indexes was observed between different individuals of the same accessions analyzed in different years: $68.83-97.79 \%$. This particular species was very susceptible to pests and diseases during the cultivation in the green-house and presented over-branching in young parts as well as dwarfism in vegetative and reproductive parts. That could maybe have caused the observed meiotic anomalies, even if the occurrence of mutations cannot be totally ruled out. Virus and other pathogens may alter cytological processes in plants. In plants of $C$. annuum and $C$. pendulum infected by viruses, several meiotic irregularities similar to those we observed (univalents, laggards, bridges, micronuclei, restitution nucleus, among others) as well as somatic polyploidy have been reported (Swaminathan et al. 1959, Mircova and Sotirova 1995).

Meiotic behavior is reported here for the first time for the $2 n=26$ species $C$. buforum, $C$. campylopodium, C. cornutum, C. pereirae, C. freiburgense, C. schottianum, C. villosum var. villo- 

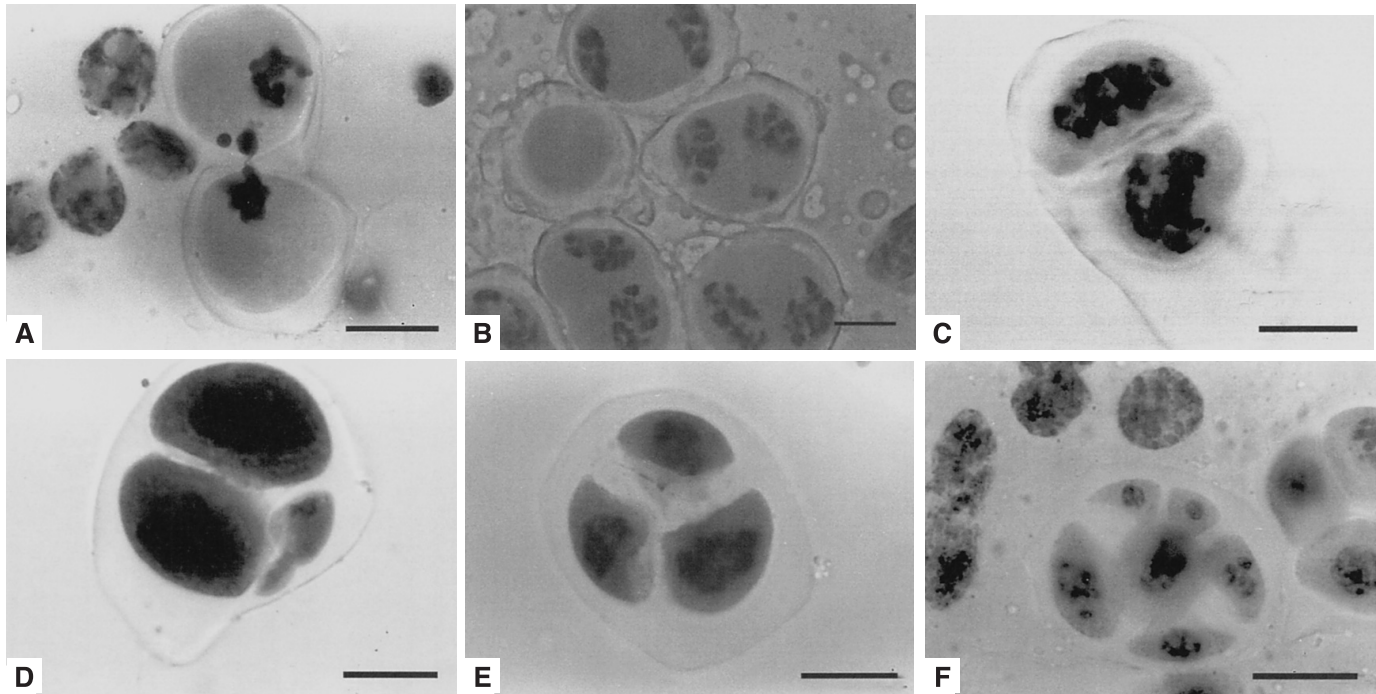

Fig. 5. Meiosis in $2 n=26$ Capsicum species. A) C. cornutum, cells with cytomixis, B and C) C. buforum: B) cell with cytoplasm but no chromosomes, C) dyad, D) C. schottianum, dyad with microcyte, E and F) C. buforum: E) tryad, F) polyad showing micronuceli and microcytes. Scale bar equal to $10 \mu \mathrm{m}$.
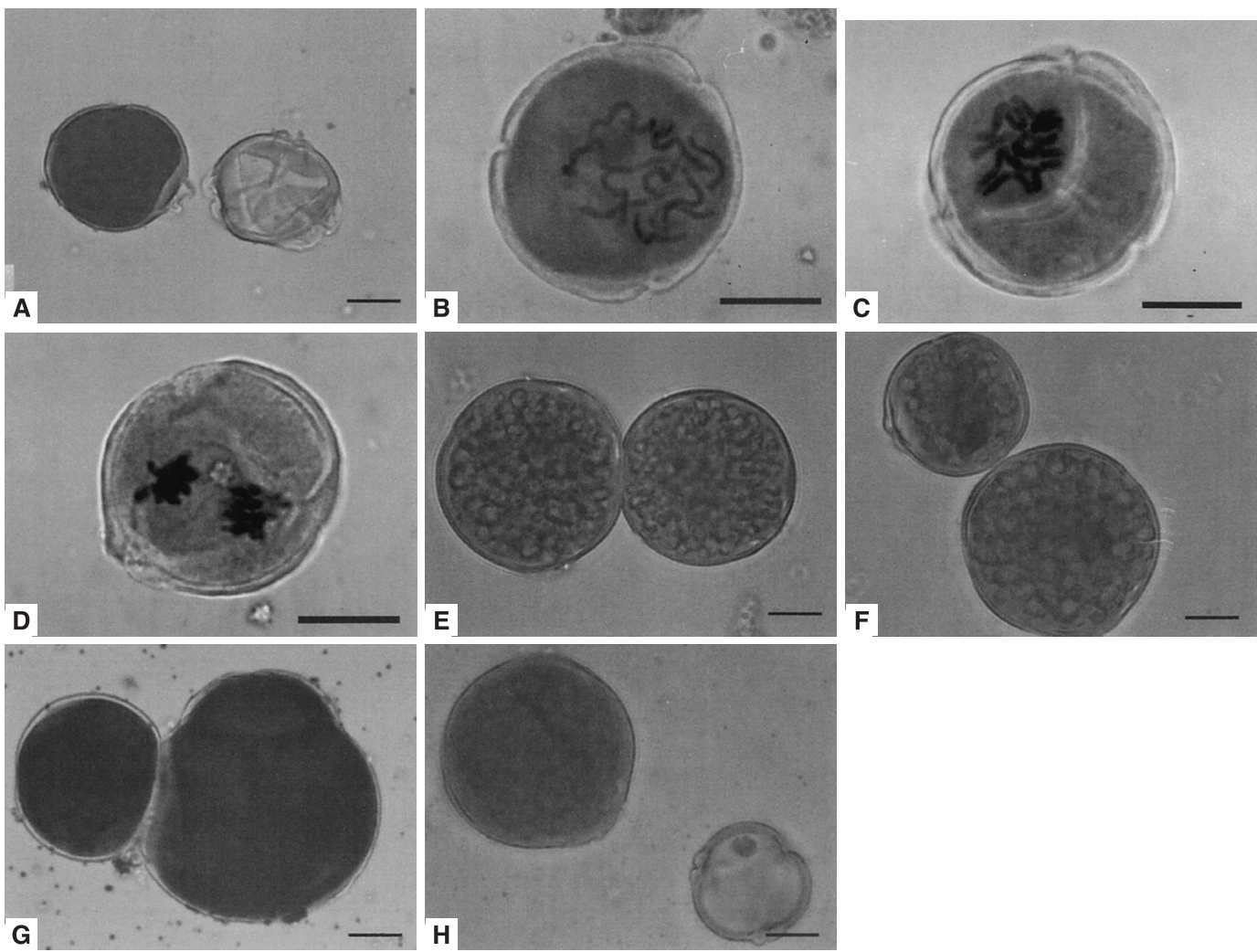

Fig. 6. Potentially viable (stained) and inviable (not-stained) pollen grains of Capsicum species: A) C. flexuosum. B-D) C. parvifolium, showing different phases of pollen mitosis, E) C. sp 2, F) C. sp 6 with pollen grains of different sizes, G) C. buforum with "giant" and normal pollen grains, D) C. cornutum with viable and inviable pollen grains. Scale bar equal to $10 \mu \mathrm{m}$. 
sum, Capsicum sp 1, Capsicum sp 2 and Capsicum sp 6. One of the characteristics of these $2 n=26$ taxa, is that the thirteenth chromosome pair is a small acrocentric (Pozzobon et al. 2006). As for the $2 n=24$ species, meiotic behavior was generally regular in the $2 n=26$ taxa (Table 2 ). In most cells and species 13 bivalents were observed at diakinesis and metaphase I (Table 2, Fig. 3A and B). The small pair formed and easily identified bivalent, normally located apart form the other associations. Secondary associations between bivalents were occasionally seen. In some cells, bivalents loosely associated were observed (Fig. 3F), probably reflecting an earlier chiasma terminalization. Chromosome disjunction at anaphases and telophases I and II were also mostly regular (Table 2, Fig. 3G).

Despite the predominant regular meiotic behavior, some irregularities were found in low frequencies (Table 2) such as non-orientation of chromosome at metaphase I (Fig. 3C), univalents, trivalents, quadrivalents and other possible multiple associations that could not be identified due to chromosome stickiness (Fig. 3D). Separation of sister chromatids at anaphase I were found in Capsicum sp. 6 (Fig. 3E), and could be due to desynapsis. Kumar and Raja Rao (1985) observed desynapsis in $C$. frutescens but could not establish its genetic basis, if any. Irregularities observed at anaphase and telophase I (Fig. 3H, 4A, 4B), pro-metaphase, metaphase, anaphase and telophase II (Fig. 4E-H) were of the same type as those found for the $2 n=24$ species. Restitution nuclei were observed (Fig. 4C and D), probably due to a reorganization of the chromosomes between prometaphase and anaphase II. Tong and Bosland (2003) reported pairing in 12 bivalents in a $2 n=24$ accession of $C$. buforum (all the accessions we examined had $2 n=26$ chromosomes) and that the presence of laggards at anaphase and telophase I was the possible cause of low pollen stainability.

A wide variation (10.81 to $100.00 \%$ ) between percentage of cells with normal chromosome disjunction, was verified among accessions within species and between species (Table 2), as for example in Capsicum sp. 6 (48.15-70.76 and $10.39-89.47 \%$ at anaphase/telophase I and anaphase/telophase II respectively) and C. buforum (10.81-55.56 and $25.13-45.45 \%$ at anaphase/telophase I and anaphase/telophase II respectively).

Other irregularities such as cytomixis (Fig. 5A), cells with different chromosome number or without any chromosome material at all (Fig. 5B) were also, if rarely, found. Cytomixis have been described for C. annuum (Lakshmi et al. 1989) and several other plants (Pagliarini 2000) but its cause is not clear.

Meiotic indexes in the $2 n=26$ species were generally lower than those found for the $2 n=24$ species, and ranged from 0.00 to $99.27 \%$ (Table 2), being lower in those accessions with high percentage of irregular disjunction, as for example in accession 3370 of Capsicum sp. $6(0.00 \%)$ and in both individuals of accession 3368 of C. buforum (43.72 and 36.09\%). Species and accessions with more meiotic irregularities in general tended to have lower meiotic indexes than those with a more regular meiosis (Table 2), even if this relation was not necessarily linear. Several types of irregularities were found at the tetrad stage, such as monads, dyads (Fig. 5C and D), triads (Fig. 5E), microcytes with different sizes (Fig. 5F). The higher number of monads, dyads and triads in Capsicum sp. 6, C. friburgense and C. buforum (Table 2) probably results form the restitution nuclei observed at meiosis I and II.

Accession 3370 of Capsicum sp. 6 differentiated from the others by its highly irregular meiotic behavior, presenting abnormalities in all phases of meiosis and a meiotic index of $0.00 \%$ (Table 2 ).

Pollen viability ranged from 73.96 to $95.98 \%$ for the $2 n=24$ species and from 58.89 to $96.92 \%$ for the $2 n=26$ ones (Table 2, Fig. 6), in most cases over $80 \%$. It should be considered that stainability estimates pollen viability and therefore we cannot be sure that all the stained pollen grains are viable. Pollen grains bigger than normal were found in those species were monads diads and tryads were observed (Fig. 6F and G). "Giant" pollen grains are considered to indicate possibly unreduced gametes (Ramsey and Schemske 1998) or at least gametes with different chromosome numbers, and have been reported also in Capsicum (Shopova 1996b, Lippert et al. 1966), being the suggested cause for the observation of twin seedlings with different chromosome numbers (Shopova 1966b). 
Besides the data presented here, the only reports on meiotic behavior of $2 n=26$ Capsicum species are those of Tong and Bosland $(1997,2003)$ for $C$. lanceolatum, who observed predominance of bivalents, but also occurrence of quadrivalents and pollen fertility of $50.00 \%$.

The irregularities we have detected may be due to genetic (meiotic mutants) or environmental factors (such as pests and diseases) but at the moment there are no sufficient informations to decide for one or the other.

The origin of the small thirteenth pair of chromosomes in the $2 n=26$ species is still controversial and rather speculative. Moscone et al. (1993) suggested it could have derived by centric fission from one of the other 12 pairs, but Pozzobon et al. (2006), in a comprehensive study on chromosome numbers of $2 n=24$ and $2 n=26$ Brazilian Capsicum species, found no cytological evidence for that. Its constancy in number and behaviour during mitosis Pozzobon et al. (2006) and meiosis (present work) supports Pickersgill $(1977,1991)$, who pointed out that this chromosome is not a B chromosome. Bianchetti (1996), examining morpho-ecological characteristics such as fruit colour and type, habitat and geographical distribution of these $x=13$ species, suggested that they represent a primitive condition and that the $x=12$ would be derived. Combining Bianchetti (1996) data and cytological results Pozzobon et al. (2006) suggested that $x=13$ is the ancestral basic number and that the 2 basic chromosome numbers represent 2 different evolutionary lines.

Concluding, it is necessary that detailed meiotic behavior studies are extended to the largest possible number of other $2 n=24$ and $2 n=26$ accessions and species, with three main objectives: help to clarify the relations of $x=12$ and $x=13$ species, investigate the origin of the small thirteenth pair (for both aims the use of in situ techniques as FISH could be very useful) and to decide if the observed meiotic irregularities are due to genetic or environmental causes.

\section{Acknowledgements}

To Dr. Andrea del Pilar de Souza Peñaloza, Ms. Sileuza Santos (EMBRAPA-CENARGEN), MSc Sabrina de Carvalho and MSc Claudia Silva (EMBRAPA-CNPH) for their help in collecting material for cytogenetic analysis and for maintaining and supplying plants and seeds. To EMBRA$\mathrm{PA}$ for financial support and a $\mathrm{PhD}$ grant to the first author.

\section{References}

Bapa Rao, N., Sri Valli, T. and Lakshmi, N. 1992. Cytogenetic studies on the interspecific hybrid Capsicum baccatum L. $\times$ C. frutescens L. and its progeny. Euphytica 59: 135-140.

Baptista-Giacomelli, F. R., Pagliarini, M. S. and Almeida, J. L. de. 2000. Elimination of micronuclei from microspores in a Brazilian oat (Avena sativa L.) variety. Genet. Mol. Biol. 23: 681-684.

Barboza, G. E. and Bianchetti, L. B. 2005. Three new species of Capsicum (Solanacaeae) and a key to the wild species from Brazil. Syst. Bot. 30: 853-871.

Bertão, M. R. 1993. Evolução cariotípica no gênero Capsicum (Solanaceae). MSc. Dissertation, Universidade de São Paulo, Escola Superior de Agricultura Luiz de Queiroz, Piracicaba.

Bianchetti, L. B. 1996. Aspectos morfológicos, ecológicos and biogeográficos de dez táxons de Capsicum (Solanaceae) ocorrentes no Brasil. MSc Dissertation, Universidade de Brasília, Brasília.

—., Bustamante, P. G., Silva, G. P. and Reifschneider, F. J. B. 1999. Relatório de viagem para coleta de espécies silvestres de Capsicum (Solanaceae), realizada entre os dias 28/4 and 26/5 de no sudeste do Brasil. http://www.cnph.embrapa.br/projetos/capsicum/indexf3sub10.htm

Carluccio, F. and Saccardo, F. 1977. Karyotype studies in Capsicum. In: Pochard, E. (Ed.) Capsicum 77: Comptes Rendus. Congrès Eucarpia sur la Genetique et la Selection du Piment, 3, INRA, Avignon-Montfavet. pp. 39-50.

Egawa, Y. and Tanaka, M. 1984. Structural differentiation of chromosomes by reciprocal translocation in Capsicum annuum. Japan. J. Breed. 34: 445-450.

Ferreira, M. A. M. M. 1998. Determinação do padrão de regiões heterocromáticas no gênero Capsicum através de métodos de bandamento. MSc. Dissertation, Universidade de São Paulo, Escola Superior de Agricultura Luiz de Queiroz, Piracicaba. 
González, M. M. and Bosland, P. W. 1991. Strategies for stemming genetic erosion of Capsicum germplasm in the Americas. Diversity 7: 52-53.

Kumar, O. A., Panda, R. C. and Raja Rao, K. G. 1987. Cytogenetic studies of the $\mathrm{F}_{1}$ hybrids of Capsicum annuum with $C$. chinense and C. baccatum. Theor. Appl. Genet. 74: 242-246.

— and Raja Rao, K. G. 1985. Desynapsis in Capsicum frutescens L. Cytologia 50: 69-73.

Lakshmi, N., Prakash, N. S., Harini, I. and Rama Rao, Y. 1989. A case of spontaneous cytomixis coupled with desynapsis in Capsicum annuum L. Cytologia 54: 287-291.

Lanteri, S. and Pickersgill, B. 1993. Chromosomal structural changes in Capsicum annuum L. and C. chinense Jacq. Euphytica 67: 155-160.

Limaye, V. A. and Patil, V. P. 1989. Karyomorphological studies in the genus Capsicum Linn. Cytologia 54: 455-463.

Lippert, L. F., Smith, P. G. and Bergh, B. O. 1966. Cytogenetics of the vegetable crops. Gardens peppers, Capsicum sp. Bot. Rev. 32: 24-55.

Love, R. M. 1949. Estudos citológicos preliminares de trigos rio-grandenses. Secretaria da Agricultura, Porto Alegre.

McLeod, M. J., Eshbaugh, W. H. and Guttman, S. I. 1979a. A preliminary biochemical systematic study of the genus Capsicum-Solanaceae. In: Hawkes, J. G., Lester, R. N. and Skelding, A. D. (Eds.). The Biology and Taxonomy of the Solanaceae. Academic Press, New York. pp. 701-713.

- , - and - 1979b. An electrophoretics study of Capsicum (Solanaceae). The purple flowered taxa. Bull. Torrey Bot. Club 106: 326-333.

—, Guttman, S. I. and Eshbaugh, W. H. 1983. Peppers (Capsicum). In: Tanksley, S. D. and Orton, T. J. (Eds.). Isozymes in Plant Genetics and Breeding, Part B. Elsevier Science Publishers B. V., Amsterdam. pp. 189-201.

- , - - — and Rayle, R. E. 1983. An electrophoretic study of evolution in Capsicum (Solanaceae). Evolution 37: 562-574.

Mircova, V. and Sotirova, V. 1995. Cytological investigation on pepper plants infected by Tobacco Mosaic Virus (TMV) in different stages of development. Capsicum Eggplant Newsl. 14: 54-55.

- and Molchova, E. 1985. Meiosis in PCM of intervarietal pepper hybrids and in late generations of the interspecific hybrid Capsicum pendulum Willd. X Capsicum annuum L. (var. nigrum). Capsicum Newsl. 4: 45-46.

Moscone, E. A. 1990. Chromosome studies on Capsicum (Solanaceae) I. Karyotype analysis in C. chacoënse. Brittonia 42: 147-154.

— 1992. Estudios de cromosomas meioticos en Solanaceae de Argentina. Darwiniana 31: 261-297.

- 1993. Estudios cromosómicos en Capsicum (Solanaceae) II. Analisis cariotípico de C. parvifolium y C. annuum var. annuum. Kurtziana 22: 9-18.

- 1999. Análisis cariotípico en Capsicum baccatum var. umbilicatum (Solanaceae) mediante bandeos Ag NOR y fluorescencia. Kurtziana 27: 225-232.

-, Lambrou, M. and Ehrendorfer, F. 1996. Fluorescent chromosome banding in the cultivated species of Capsicum (Solanaceae). Pl. Syst. Evol. 202: 37-63.

-, - , Hunziker, A. T. and Ehrendorfer, F. 1993. Giemsa C-banded karyotypes in Capsicum (Solanaceae). P1. Syst. Evol. 186: $213-229$.

—, Loidl, J., Ehrendorfer, F. and Hunziker, A. T. 1995. Analysis of active nucleolus organizing regions in Capsicum (Solanaceae) by silver staining. Amer. J. Bot. 82: 276-287.

Novák, F. and Betlach, J. 1970. Meiotic irregularities in pollen sterile sweet pepper (Capsicum annuum L.). Cytologia 35: 335-343.

Otha, Y. 1961. Cytogenetical studies in the genus Capsicum, I. C. frutescens $\times$ C. annuum. Jpn. J. Genet. 36: 647-651.

Pagliarini, M. S. 2000. Meiotic behavior of economically important plant species: the relationship between fertility and male sterility. Genet. Mol. Biol. 23: 997-1002.

Panda, R. C., Aniel Kumar, O. and Raja Rao, K. G. 2004. Cytogenetic studies of some F $_{1}$ hybrids between wild and cultivated taxa of Capsicum L. Cytologia 69: 203-208.

Park, Y.-K., Park, K.-C., Park, C.-H. and Kim, N.-S. 2000. Chromosomal localization and sequence variation of 5Sr RNA gene in five Capsicum species. Mol. Cells 10: 18-24.

Pickersgill, B. 1971. Relationships between weedy and cultivated forms in some species of chili peppers (Genus Capsicum). Evolution 25: 683-691.

— 1977. Chromosomes and evolution in Capsicum. In: Pochard, E. (Ed.) Capsicum 77: Comptes Rendus. Congrès Eucarpia sur la Genetique et la Selection du Piment, 3, INRA, Avignon-Montfavet. pp. 27-37.

- 1984. Migration of Chili Peppers, Capsicum spp, in the Americas. In: Store, P. (Ed.) Pré-columbian plant migration. Papers of the Peabody Museum of Archaelogy and Ethnology Vol. 76. Harvard University Press., Cambridge. pp. $105-123$.

- 1991. Cytogenetics and evolution of Capsicum L. In: Tsuchiya, T. and Gupta, P. K. (Eds.). Chromosome Engineering in Plants: Genetics, Breeding, Evolution. Part B. Elsevier, Amsterdam. pp. 139-160.

Pozzobon, M. T., Schifino-Wittmann, M. T. and Bianchetti, L. B. 2006. Chromosome numbers in wild and semidomesticated Brazilian Capsicum L. (Solanaceae) species: do $x=12$ and $x=13$ represent two evolutionary lines? Bot. J. Linn. 
Soc. 151: 259-269.

Raghuvanshi, R. K. and Saxena, A. 1991. Cytogenetical study in inter-varietal crosses of Capsicum annuum L. Capsicum Newsl. 10: 35-36.

Ramsey, J. and Schemske, D. W. 1998. Pathways, mechanisms, and rates of polyploidy formation in flowering plants. Annu. Rev. Ecol. Syst. 29: 467-501.

Saccardo, F. and Ramulu, K. S. 1977. Cytological investigatins in the genus Capsicum. In: Pochard, E. (Ed.) Capsicum 77: Comptes Rendus. Congrès Eucarpia sur la Genetique et la Selection du Piment, 3, INRA, Avignon-Montfavet. pp. 51-66.

Shopova, M. 1966a. Studies in the genus Capsicum. I. Species differentiation. Chromosoma 19: 340-348.

— 1966b. Studies in the genus Capsicum. II. Irregularities in the pollen mother cells. Chromosoma 19: 349-356.

Swaminathan, M. S., Ninan, T. and Magoon, M. L. 1959. Effects of virus infection on microsporogenesis and seed fertility in Capsicum. Genetica 30: 63-69.

Tong, N. and Bosland, P. W. 1997. Meiotic chromosome study of Capsicum lanceolatum, another 13 chromosome species. Capsicum Eggplant Newsl. 16: 42-43.

— and - 1999. Capsicum tovarii, a new member of the Capsicum baccatum complex. Euphytica 109: 71-77.

- and - 2003. Observations on interspecific compatibilty and meiotic chromosome behavior of Capsicum buforum and C. lanceolatum. Gen. Res. Crop Evol. 50: 193-199. 